Volume 2

\title{
How to Remedy the Court's Unreasonable Expansion of the Public Use Doctrine
}

Brian Walsh

Touro Law Center

Follow this and additional works at: https://scholarship.law.tamu.edu/journal-of-property-law

Part of the Law Commons

\section{Recommended Citation}

Brian Walsh, How to Remedy the Court's Unreasonable Expansion of the Public Use Doctrine, 2 Tex. A\&M J. Real Prop. L. 169 (2014).

Available at: https://doi.org/10.37419/JPL.V2.11.8

This Student Article is brought to you for free and open access by Texas A\&M Law Scholarship. It has been accepted for inclusion in Texas A\&M Journal of Property Law by an authorized editor of Texas A\&M Law Scholarship. For more information, please contact aretteen@law.tamu.edu. 


\title{
HOW TO REMEDY THE COURT'S UNREASONABLE EXPANSION OF THE PUBLIC USE DOCTRINE
}

\author{
By Brian Walsh†
}

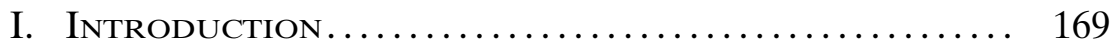

II. Evolution of the Public use Doctrine ........... 170

A. Early Eminent Domain Doctrine................ 172

B. "Protecting the Public Welfare" as a Public Use ... 174

C. Public Use Examined Under Rational Basis

Scrutiny.................................. 176

D. "Public Purpose" as a Public Use................ 177

III. The Reaction to the Public Use Expansion ....... 178

IV. A Proposal for the Future of the Public Use ReQuirement .............................. 181

A. The Definition of Public Use Must Fall Within the Original Intent of the Founders ............... 182

B. The Right to Property Is a Fundamental Right and Must Be Subject to Strict Judicial Scrutiny ......... 183

V. Conclusion .................................. 185

\section{INTRODUCTION}

The Takings Clause of the Fifth Amendment protects the individual's right to own private property without interference from the government. ${ }^{1}$ However, possibly as a result of relatively scant historical documentation of the founder's original intent in framing the Fifth Amendment as a limitation on the government's power of eminent domain, the interpretation of the Takings Clause has evolved significantly over time. ${ }^{2}$ Generally, governmental takings must satisfy two requirements: (1) the property must be taken for a public use; and (2) the owner must be justly compensated for his land. ${ }^{3}$ While early case law exclusively describes land taken for public use as including "forts, armories, and arsenals, . . . navy-yards and light houses, for custom houses, post offices, and court houses," ${ }^{4}$ the broad modern view of

$\dagger$ Third year law student at Touro Law Center, member of the Touro Law Review, Municipal Law Fellow, and Honors Scholar.

I would like to thank Professor Sarah Adams-Schoen for her guidance and encouragement.

1. U.S. Const. amend. V.

2. See, e.g., Kohl v. United States., 91 U.S. 367, 368 (1875); Berman v. Parker, 348 U.S. 26 (1954); See Kelo v. City of New London, 545 U.S. 469 (2005); see generally Sara B. Falls, Waking A Sleeping Giant: Revisiting the Public Use Debate Twenty-Five Years After Hawaii Housing Authority v. Midkiff, 44 WAshburn L.J. 355 (2005).

3. Kelo, 545 U.S. at 476.

4. Kohl, 91 U.S. at 371.

DOI: https://doi.org/10.37419/JPL.V2.I1.8 
public use includes expansive concepts such as economic revitalization. ${ }^{5}$ This expansion of the definition of what constitutes a public use is beyond the scope of the founders' intent. The individual's right to property is an enumerated fundamental right of the Fifth Amendment, ${ }^{6}$ and any purported violation of this right must be met with the same strict scrutiny by the courts as any other violation of a fundamental right.

This Comment will deal with the evolution of the public use requirement in Part II. Part III deals with the unnecessary expansion of the definition of a public use. In Part IV I will argue why the courts should return to a public use definition in line with the intent of the Fifth Amendment as written by the founders.

\section{Evolution of the Public Use Doctrine}

The Fifth Amendment provides that: "No person shall be ... deprived of life, liberty, or property, without due process of law; nor shall private property be taken for public use, without just compensation." "7 Much of the debate over the meaning of the Takings Clause is fueled by the interpretation of historical documentation regarding its drafting and inclusion in the Bill of Rights. ${ }^{8}$ Additionally, this area of law has grown increasingly controversial, as clear definitions of property, taking, and public use have not been agreed upon. For example, property has been vaguely described as "an elaborate bundle of customs, rights, expectations, and obligations regarding the relationships among individuals, society, and the state." ${ }^{\prime}$ In some instances, such as in Nollan v. California Coastal Commission, the Justice writing the majority opinion outlines a number of different definitions of property. ${ }^{10}$

An explanation of the right to property has proven to be equally elusive. While it is generally accepted by modern legal scholars ${ }^{11}$ that Lord William Blackstone has come closest to defining the right to property as "the free use, enjoyment, and disposal of all . . a acquisi-

5. Kelo, 545 U.S. at 483.

6. See U.S. Const. amend. V.

7. Id.

8. See, e.g., Matthew P. Harrington, "Public Use" and the Original Understanding of the So-Called "Takings" Clause, 53 Hastings L.J. 1245, 1246 (2002); Jonathan Lahn, The Uses of History in the Supreme Court's Takings Clause Jurisprudence, 81 Chi.-Kent L. Rev. 1233, 1260 (2006).

9. Daniel A. Ippolito, An Originalist's Evaluation of Modern Takings Jurisprudence, 26 Seton Hall L. Rev. 317, 322 (1995) (citing Jesse Dukeminier \& James Krieir, Property 86 (3d ed. 1993)).

10. See, e.g., Nollan v. Cal. Coastal Comm'n, 483 U.S. 825, 841 (1987); Andrea L. Peterson, The Taking Clause: In Search of Underlying Principles Part I-A Critique of Current Takings Clause Doctrine, 77 CAL. L. Rev. 1299, 1316 n.7 (1989).

11. See, e.g., Ippolito, supra note 9, at 322 n.36; Douglas W. Kmiec, The Original Understanding of the Taking Clause Is Neither Weak Nor Obtuse, 88 Colum. L. Rev. 1630, 1635 (1988). 
tions, without any control or diminution, save only by the laws of the land," 12 even this definition fails to provide a clear demarcation of what interest in property the Constitution purportedly protects. For example, it is not clear whether under Lord Blackstone's definition a local land ordinance requiring a permit for tree removal would qualify as a "law of the land" that would hinder a landowner's "free use" of his property.

The definition of a taking is more concrete, but nevertheless is not without its own share of controversy. In the area of Fifth Amendment jurisprudence, a taking of property can occur in two ways. The first is a direct, physical taking, the definition of which is relatively uncontroversial. ${ }^{13}$ The other, far more contentious taking is known as a regulatory taking. ${ }^{14}$ A regulatory taking occurs when the government enacts a regulation that takes away an intangible property right, or diminishes property value by limiting its use. ${ }^{15}$ While a number of modern commentators have interpreted the Takings Clause to regulate only direct, physical takings of property,${ }^{16}$ the Supreme Court has recognized regulatory takings as well. ${ }^{17}$ However, the Court, by its own admission, has never provided a justification for the rule of regulatory takings. ${ }^{18}$ Nevertheless, the Court has frequently held that when regulation denies any economically beneficial use of the land, a regulatory taking has occurred. ${ }^{19}$

Just as a firm definition of property and a taking has proven elusive, so has a definition of a public use. The definition of public use has evolved along with society, environmental science, and the progression of the function of government in the forum of property develop-

12. See 1 William Blackstone, Commentaries at 138.

13. Lucas v. S.C. Coastal Council, 505 U.S. 1003, 1014 (1992) (showing a "direct appropriation" of property is covered under the Takings Clause).

14. See Andrew S. Gold, Regulatory Takings and Original Intent: The Direct, Physical Takings Thesis "Goes Too Far", 49 AM. U. L. REv. 181, 242 (1999) ("It is quite possible, but far from clear, that the original understanding of the Takings Clause included regulatory takings. Original intent may raise questions regarding the current incarnation of regulatory takings law, but it hardly resolves the question of whether regulatory takings deserve compensation generally.").

15. Id. at 232 n.314; see also Woodruff v. Neal, 28 Conn. 165, 170 (1859) (requiring compensation for regulation that took usage rights from landowners by requiring them to allow others to graze cattle on their land).

16. See William Michael Treanor, The Origins and Original Significance of the Just Compensation Clause of the Fifth Amendment, 94 YALE L.J. 694, 711 (1985).

17. See Lucas, 505 U.S. at 1015-1016 ("As we have said on numerous occasions, the Fifth Amendment is violated when land-use regulation 'does not substantially advance legitimate state interests or denies an owner economically viable use of his land." ") (emphasis in original).

18. Id. at 1017 ("We have never set forth the justification for [the regulatory takings] rule. Perhaps it is simply, as Justice Brennan suggested, that total deprivation of beneficial use is, from the landowner's point of view, the equivalent of a physical appropriation.").

19. Id. at 1019 . 
ment. ${ }^{20}$ At first, public uses encompassed takings simply for "use by the public," 21 and included, for example, the taking of private land for the purpose of building railroad tracks. ${ }^{22}$

However, as eminent domain cases became more complex and the line between public and private use became blurred, courts found this standard to be unworkable. ${ }^{23}$ Recently, the Court has gone so far as to include economic revitalization-from blight removal to simply acquiring and developing land for the purpose of increased tax revenue-greatly expanding the government's power of eminent domain. ${ }^{24}$

Broadly speaking, a two-step test is used when determining whether a taking for a public use violates the Constitution. ${ }^{25}$ The state must first show that its use of eminent domain is rational, and then prove the taking is related to a conceivable governmental purpose. ${ }^{26}$ Notably, this level of judicial scrutiny is highly deferential to the government, normally reserved for rights deemed by the courts to not be fundamental under the Constitution.

\section{A. Early Eminent Domain Doctrine}

In order to better understand the significance of the public use doctrine in the Takings Clause, we must first examine its history. The power of eminent domain (a phrase coined in the seventeenth century by the legal scholar Hugo Grotius) is broadly defined as the sovereign's inherent power to have control over its own lands, ${ }^{27}$ and has been traced as far back as the Early Roman Empire. ${ }^{28}$ In England, the sovereign power of the king to acquire any property deemed necessary to the crown was remarkably broad. ${ }^{29}$ Further, the land taken by the king was routinely taken without compensation to the landowner. ${ }^{30}$ In contrast, property acquisition was markedly different in the colonies, as settlers were given sole title of small plots of land upon arriving in America. ${ }^{31}$

20. 26 Am. Jur. 2d Eminent Domain $\S 44$ (2014).

21. See Fallbrook Irr. Dist. v. Bradley, 164 U.S. 112, 161 (1896).

22. Aldridge v. Tuscumbia, C. \& D.R. Co., 2 Stew. \& P. 199, 201 (1832).

23. Kelo v. City of New London, 545 U.S. 469, 485 (2005).

24. See id. at 483.

25. $I d$. at 476.

26. Hawaii Hous. Auth. v. Midkiff, 467 U.S. 229, 241 (1984).

27. Katherine M. McFarland, Privacy and Property: Two Sides of the Same Coin: The Mandate for Stricter Scrutiny for Government Uses of Eminent Domain, 14 B.U. Pub. Int. L.J. 142, 144 (2004).

28. Steven E. Buckingham, Case Comment, The Kelo Threshold: Private Property and Public Use Reconsidered, 39 U. Rich. L. Rev. 1279, 1295 n.127 (2005).

29. McFarland, supra note 27, at 145.

30. Id.

31. Id. 
The founders sought to permanently protect the citizens' right to property. ${ }^{32}$ One of the most vocal sponsors of this protection, James Madison, stated, "Government is instituted to protect property of every sort. This being the end of government, that alone is a just government, which impartially secures to every man, whatever his own." 33 While Madison recognized eminent domain as a power inherent in the sovereign, he was greatly influenced by the writings of John Locke, who was a staunch advocate for personal property rights. ${ }^{34}$ Therefore, by requiring that land taken be for a public use, ${ }^{35}$ it appears Madison intended to limit the government from arbitrarily taking land. ${ }^{36}$

Early American Supreme Court jurisprudence interpreting the Fifth Amendment recognized the power of eminent domain as essential to that of a sovereign government. ${ }^{37}$ The practice of eminent domain has historically been used in the United States to procure land for building public utilities such as railroads, public roads, schools, and post offices. ${ }^{38}$ This was generally accepted in early American society, as the federal government was not forced to cite the power of eminent domain in a Supreme Court case until $1875 .{ }^{39}$

In Kohl v. United States, ${ }^{40}$ the federal government invoked the power of eminent domain to procure lands in Cincinnati to be used for a post office. ${ }^{41}$ The Court took the opportunity to lay a strong judicial foundation for the protection of the government's power of eminent domain. Furthermore, the Court held that the eminent domain powers vested "by the Constitution in the general government

32. Id.

33. McFarland, supra note 27 at 142 (citing James Madison, Property National Gazette (Philadelphia) Mar. 29, 1772, at 174).

34. Id. at 145; William Michael Treanor, The Original Understanding of the Takings Clause and the Political Process, 95 Colum. L. Rev. 782, 817 n.185 (1995).

35. See Matthew P. Harrington, "Public Use" and the Original Understanding of the So-Called "Takings" Clause, 53 Hastings L.J. 1245, 1248 (2002) (explaining that an argument has been made that the text of the Takings Clause requires the government to compensate landowners only for land taken for a public use and takings via taxation are not compensable; therefore, the public use language in the Fifth Amendment is meant to be descriptive, not proscriptive).

36. See generally McFarland, supra note 27, at 145; Treanor supra note 16, at 709 (discussing further evidence of Madison's intention to protect citizens' rights to property).

37. See, e.g., United States v. City of Chicago, 48 U.S. 185, 194 (1849) ("It is not questioned that land within a State purchased by the United States as a mere proprietor, and not reserved or appropriated to any special purpose, may be liable to condemnation for streets or highways, like the land of other proprietors, under the rights of eminent domain.").

38. See City of Chicago, 48 U.S. at 194.

39. Kohl v. United States, 91 U.S. 367, 371 (1875); see also Donald J. Kochan, "Public Use" and the Independent Judiciary: Condemnation in an Interest-Group Perspective, 3 TeX. Rev. L. \& POL. 49 (1998).

40. Kohl, 91 U.S. at 367.

41. Id. at 377. 
demand for their exercise the acquisition of land in all States." 42 Just as each person is a citizen of his state, and subject to each state's power of eminent domain, so too are the individual states subject to the eminent domain power of the federal government. ${ }^{43}$ Thus, the issue in $\mathrm{Kohl}$ was as much about the issue of eminent domain as it was about federalism. The Court delineated a helpful list of public uses, including "forts, armories, and arsenals, for navy-yards and light houses, for custom houses, post offices, and court houses," that could be used by the federal government as a framework for legitimate public uses. ${ }^{44}$ By giving examples of proper public uses, the Court made clear that the acquisition of land by the federal government cannot be contingent on the approval of any private citizen or state government. Instead, the government may take an individual's land against his will, as long as the use is for an acceptable public purpose. ${ }^{45}$ This was the Court's first attempt at balancing individual property rights with the government's power of eminent domain.

\section{B. "Protecting the Public Welfare" as a Public Use}

As the United States recovered from the Second World War, the government began to pass nationwide programs aimed at redeveloping economically depressed urban areas. ${ }^{46}$ Congress passed one such program, called the District of Columbia Redevelopment Act, in 1945. ${ }^{47}$ The purpose of the Act was to condemn economically distressed areas in the District of Columbia and redevelop the land through a designated agency appointed by Congress. Residential property owners within one targeted area (whose property was not itself economically distressed but was surrounded by distressed property) brought suit challenging the power of Congress to use its eminent domain power to obtain property "merely to develop a more balanced, attractive community." 48

In 1954, the Supreme Court responded by expanding upon the list of justifications for the use of eminent domain for the first time since Kohl. ${ }^{49}$ In Berman v. Parker, a unanimous Court held in favor of the government's plan for using eminent domain for the purpose of economic redevelopment. ${ }^{50}$ The Court held that Congress had made a legislative determination that the land needed to be condemned and acquired using its eminent domain powers for the benefit of the public

42. Id. at 368 .

43. $I d$.

44. Id.

45. Kohl, 91 U.S. at 371.

46. Martin E. Gold \& Lynne B. Sagalyn, The Use and Abuse of Blight in Eminent Domain, 38 Fordham URB. L.J. 1119, 1121 (2011).

47. See Berman v. Parker, 348 U.S. 98 (1954).

48. Id. at 101-02.

49. Id.

50. Kohl, 91 U.S. 367 (1875). 
welfare, a concept the Court described as "broad and inclusive." 51 Protecting the public welfare, the Court stated, is inherent in the police powers of each state. ${ }^{52}$ Public welfare is defined as a product of "legislative determinations addressed to the purposes of government, purposes neither abstractly nor historically capable of complete definition." 53

Within this concept of protecting the public welfare, Congress is responsible for making determinations with regard to the health, cleanliness, and balance of the community. ${ }^{54}$ Once Congress has made its determinations using a wide variety of values, it is not the job of the judiciary to reassess them. ${ }^{55}$ The Court went on to describe the government's power of eminent domain as a means to an end. ${ }^{56}$ The method of acquisition is irrelevant, as long as Congress has determined that the acquisition itself is for a public purpose. ${ }^{57}$

The Berman decision was significant for a number of reasons. First, it greatly expanded the government's power to acquire property. As long as the legislative body invoking its eminent domain power does so for the purpose of a public use, as defined by that same legislative body, the judiciary has no basis for review. ${ }^{58}$ Further, in an effort to avoid a holdout by a single landowner, the Court again deferred to the legislature to determine the breadth of each project, as "community redevelopment programs need not, by force of the Constitution, be on a piecemeal basis." 59 By disavowing even a rational basis of review, the Court arguably relinquished any responsibility for reviewing legislative public use determinations. ${ }^{60}$ In announcing that public use determinations are inherent in the police powers of the State, the Court placed such determinations outside the purview of the judiciary to examine.

Finally, the Court acknowledged that blight removal, in addition to slum clearance, is well within the definition of a public use. ${ }^{61}$ Prior to the Berman decision, eminent domain was used by legislators for the clearance of inner city slums. ${ }^{62}$ Following Berman, not only does the legislature have an interest in clearing unlivable housing, it also has the power to "determine that the community should be beautiful as

51. Id.

52. Berman, 348 U.S. at 102.

53. $I d$.

54. $I d$.

55. Id. at 103 (citing Luxton v. N. River Bridge Co., 153 U.S. 525, 529-30 (1894)).

56. $I d$.

57. Berman, 348 U.S. at 103.

58. Id.

59. Id. at 104 .

60. McFarland, supra note 27, at 148.

61. Berman, 348 U.S. at 103-04.

62. See Olga V. Kotlyarevskaya, "Public Use" Requirement in Eminent Domain Cases Based on Slum Clearance, Elimination of Urban Blight, and Economic Development, 5 Conn. Pub. Int. L.J. 197, 203 (2006). 
well as healthy, spacious as well as clean, well-balanced as well as carefully patrolled." 63 Due to this abstract expansion of what constitutes a public purpose, legislatures have been granted almost unfettered access to private property for any conceivable reason.

\section{Public Use Examined Under Rational Basis Scrutiny}

Thirty years after the Berman decision, the Supreme Court was again confronted with the issue of the public use doctrine in Hawaii $v$. Midkiff. ${ }^{64}$ In the 1950s and 1960s, the ownership of Hawaiian land gradually became more consolidated into a land oligopoly; whereby the vast majority of the land in Hawaii was owned by a relatively small percentage of the population, with the remainder of citizens as lessors of smaller parcels. ${ }^{65}$ In order to "reduce the perceived social and economic evils" of this system of land ownership, the Hawaiian legislature enacted the Land Reform Act of 1967. ${ }^{66}$ The Act formed a system of condemnation whereby title of the smaller parcels of land were taken from the lessors and transferred to the lessees in order to reduce the concentration of land ownership. ${ }^{67}$ The determination of whether or not the state's acquisition of each parcel of land was to "effectuate the public purposes" of the Act was made individually by the Hawaiian Housing Authority. ${ }^{68}$ This led the relatively few landowners of Hawaii to challenge the law based on their claim that the condemnation of their property for sale to their lessees violated the public use requirement of the Fifth Amendment.

Justice O'Connor wrote a unanimous opinion that built upon the definition of public use described in Berman as "coterminous with the scope of a sovereign's police powers." ${ }^{69}$ However, the Court acknowledged in Berman a role for the courts to play in reviewing the judgment of a legislature as to what constitutes a public use, albeit "an extremely narrow one."70 This extremely narrow form of judicial review may come only when the public use determination is "shown to involve an impossibility." 71 In order to avoid judicial interference in legislative findings, the Court may only examine a public use determination if the use is "palpably without reasonable foundation."72 Thus, the Midkiff Court outlined some sort of judicial check on the power of the legislature to condemn property for a public use, albeit a relatively small one.

63. Berman, 348 U.S. at 33.

64. Hawaii Hous. Auth. v. Midkiff, 467 U.S. 229, 241 (1984).

65. Id. at 229.

66. Id.

67. Id. at 230 .

68. Id.

69. Hawaii Hous. Auth., 467 U.S. at 240.

70. Id.

71. Id. at 241.

72. Id. (citing United States. v. Gettysburg Elec. R. Co., 160 U.S. 668, 680 (1896)). 
In doing so, the Court introduced what is commonly known as a rational basis of review for public use determinations. When the exercise of eminent domain power is rationally related to a conceivable public purpose, the Court will find the taking to be within the boundary of the Fifth Amendment. ${ }^{73}$ In applying this basis of review, the Midkiff Court had no trouble finding that Hawaii's Land Reform Act of 1967 was constitutional. ${ }^{74}$ The Court saw the Act as a comprehensive and rational approach to curing a market failure. ${ }^{75}$ Whether this approach would actually correct the market failure was irrelevant because the constitutional public use requirement is "satisfied as long as the legislature rationally could have believed that the Act would promote its objective."76

In the latter part of its decision, the Court dealt with the issue of whether or not this transfer of land was a purely private taking, as was contended by the Hawaiian landowners. A purely private taking, that is, a taking for no reason other than to "confer a private benefit on a particular private party," cannot survive the scrutiny of the public use requirement. ${ }^{77}$ However, in this case the Court found the Act not to benefit a particular class of individuals, but to "attack certain perceived evils of concentrated property ownership in Hawaii-a legitimate public purpose." ${ }^{\prime 7}$ As this public purpose was not irrational in the eyes of the Court, the requirements of the Fifth Amendment were met.

\section{D. "Public Purpose" as a Public Use}

In 2005, the Court again tackled the issue of what constitutes a public use. In Kelo v. City of New London, the Court was forced to directly decide whether legislatures may use economic revitalization as a justification for exercising their eminent domain powers. ${ }^{79}$

The decision addressed a development plan approved by the City of New London, Connecticut, aimed at "revitaliz[ing] an economically distressed city." 80 This plan was preceded by a determination in 1990 by a state agency that the city of New London was a "distressed municipality." 81 The development plan passed in 2000 designated a private non-profit agency, the New London Development Corporation ("NLDC"), to be in charge of the implementation of the revitalization

73. $I d$.

74. Hawaii Hous. Auth., 467 U.S. at 241.

75. Id. at 242 .

76. Id. (citing W. \& S. Life Ins. Co. v. State Bd. of Equalization, 451 U.S. 648, 671-72 (1981)).

77. Id. at 245 .

78. Id.

79. Kelo v. City of New London 545 U.S. 469, 472 (2005).

80. Id. at 472 .

81. Id. at 473 . 
plan. ${ }^{82}$ The plan itself was meant to create jobs, generate tax revenue, make the City more attractive, and "create leisure and recreational opportunities." 83 The NLDC targeted real estate in a ninety-acre area, and began making offers to the landowners within the area for acquisition of the property. While some landowners accepted the offers, some residents refused, including the petitioners in this case, and the NLDC initiated condemnation proceedings that gave rise to the suit. $^{84}$

The Kelo case gave the Court an opportunity to reiterate some of its previous eminent domain determinations, while also broadening the definition of public use. While the plan was found to not benefit a particular class of individuals, some of the land to be acquired was not to be used by the general public. ${ }^{85}$ A section of the property to be acquired was earmarked for commercial space for private businesses. ${ }^{86}$ Still, the Court cited the continuous expansion of the public use requirement, finding that the definition of public use was "use by the public" which was an unworkable standard. ${ }^{87}$ In doing so, the Court embraced a broader and "more natural interpretation of public use as "public purpose." "88 While the term "public purpose" had been used previously in Supreme Court eminent domain cases, this was the first time the Court unambiguously adopted the much broader public purpose definition of public use.

Writing for the majority, Justice Stevens found economic revitalization to be a sufficient public purpose, satisfying the public use requirement of the Fifth Amendment. ${ }^{89}$ While the City was not confronted with the need to remove blight, the Court found that the City's determination that the area was sufficiently distressed as to justify a program of economic rejuvenation was entitled to the Court's deference..$^{90}$ In comparing the City's goals to those of the legislatures in Midkiff and Berman, the Court held it had no basis to exempt economic development from its "traditionally broad understanding of public purpose." $" 91$

\title{
III. The Reaction to the Public Use Expansion
}

Some scholars argue the courts have greatly expanded upon the original meaning of public use within the Takings Clause, ${ }^{92}$ while

\author{
82. Id. at 475 . \\ 83. Id. at $474-75$. \\ 84. Kelo, 545 U.S. at $474-75$. \\ 85. Id. at 479 . \\ 86. Id. at 480 . \\ 87. Id. at 485 . \\ 88. Id. at 480 . \\ 89. Kelo, 545 U.S. at 485. \\ 90. Id. at 483 . \\ 91. Id. at 485 . \\ 92. See, e.g., McFarland, supra note 27; Kochan, supra note 39.
}


others believe the public use clause is merely a derscription of a compensable taking. ${ }^{93}$ Many scholars look for evidence of the intent of the founders to create a solid definition of what constitutes a public use. ${ }^{94}$ While some scholars see the attitudes at the time of the founding of the United States as fiercely protective of property rights, ${ }^{95}$ others have interpreted historical documents as showing the recent judicial view of public use within the Fifth Amendment is in furtherance of how colonial law and the early U.S. government regulated land. ${ }^{96}$

In support of her argument that the expansion of the judicial definition of a public use is unjustified, Katherine McFarland points out that the courts have continually asked the legislatures for increasingly higher levels of justification for encroachments on individual rights outside the takings arena. ${ }^{97}$ While courts continue to question government intrusion into citizens' freedom of expression and equal protection, the level of scrutiny courts give to government takings has consistently diminished over the past half century. ${ }^{98}$ By implementing a reverence to unchecked legislative determinations of what constitutes a public use, the door has been opened for misuse of the eminent domain power. ${ }^{99}$

Frequently, scholars who argue against the expansion of the public use definition point to the potential for legislative abuse of eminent domain brought on by powerful special interests. Examples that purport to show this include large companies using the legislature to condemn property needed for strip malls and casinos. ${ }^{100}$ As the argument goes, this continued expansion of the public use definition has made enforcement of the public use requirement impossible, will lead to a

93. See, e.g., Harrington, supra note 8, at 1248.

94. See, e.g., McFarland, supra note 27, at 144 ("To understand the true purpose of the eminent domain power, it is necessary to look both to its historical use and the understanding of property rights at the time of the nation's founding."); William Michael Treanor, supra note 16; John F. Hart, Colonial Land Use Law and Its Significance for Modern Takings Doctrine, 109 Harv. L. REv. 1252 (1996).

95. See, e.g., Bernard H. SAigen, Land Use Without Zoning 227 (1972).

96. See, e.g., Hart, supra note 94, at 1281. ("Property ownership was 'not an absolute right that exempted the individual owner from corporate oversight,' but rather 'a right of stewardship that the public entrusted to an individual, for both private and public benefit.'") (citing Barry A. Shain, The Myth of American Individualism: The Protestant Origins of American Political Thought 183 (1994)).

97. McFarland, supra note 27, at 142.

98. See Stephen J. Jones, Trumping Eminent Domain Law: An Argument for Strict Scrutiny Analysis Under the Public Use Requirement of the Fifth Amendment, 50 SYRACUSE L. Rev. 285, 287 (2000) ("The conclusion that follows is that so far as the federal courts are concerned neither the state legislatures nor Congress need be concerned about the public use test in any of its ramifications.").

99. Id.

100. See, e.g., Casino Reinvestment Dev. Auth. v. Banin, 727 A.2d. 102 (N.J. Super. 1998); Poletown Neighborhood Council v. City of Detroit, 304 N.W.2d 455 (Mich. 1981); Walser Auto Sales, Inc. v. City of Richfield, 644 N.W.2d 425 (Minn. 2002). 
distortion of natural market forces, and could cause a detrimental effect on states unwilling to use the courts' broadened definition. ${ }^{101}$

While Justice Kennedy, in his concurring opinion, wrote that the City of New London's plan did not warrant a more stringent standard of judicial review, he opined that a more narrowly drawn category of takings may be appropriate for increased judicial scrutiny. ${ }^{102}$ One category may be "private transfers in which the risk of undetected impermissible favoritism of private parties is so acute that a presumption of invalidity is warranted under the Public Use Clause." ${ }^{03}$ In the Kelo case, the private parties were unknown at the time of the drafting of the redevelopment plan. ${ }^{104}$ Justice Kennedy seemed to hint that if a legislature draws up a plan with a specific private party involved for development, suspicions of favoritism may lead to a rebuttable presumption of invalidity. ${ }^{105}$ Justice Kennedy did not flesh out this alternative "test" for examining public use determinations, he only specified that eminent domain disputes must be decided based on the specific facts of each case. Nevertheless, the inclusion of a private developer at the latter stages of planning by the City of New London was not enough in the eyes of Justice Kennedy to justify an exception to the public use doctrine developed through Midkiff and Berman.

On the forefront of the backlash from the Kelo decision were the four dissenting Justices. Justice O'Connor wrote the dissenting opinion, joined by Chief Justice Roberts, Justice Scalia, and Justice Thomas. ${ }^{106}$ Justice O'Connor's main argument was that, by allowing private property to be taken "under the banner of economic development," all private property may now be vulnerable to a governmental taking, as long as the legislature deems that the new party will use it in a more publicly beneficial way. ${ }^{107}$ Not only is all private property now vulnerable to governmental taking, Justice O'Connor wrote, but to hold that "the incidental public benefits resulting from the subsequent ordinary use of private property render economic development takings 'for public use' is to wash out any distinction between private and public use of property - and thereby effectively to delete the words "for public use' from the Takings Clause." 108

Justice O'Connor goes on to question the Court's reliance on the "secondary benefits" to be enjoyed by the public, as a result of the

101. Kristi M. Burkard, No More Government Theft of Property! A Call to Return to A Heightened Standard of Review After the United States Supreme Court Decision in Kelo v. City of New London, 27 Hamline J. Pub. L. \& PoL'y 115, 132 (2005-2006). 102. Kelo v. City of New London, 545 U.S. 469, 493 (2005) (Kennedy, J., concurring).

103. $I d$.

104. Id.

105. $I d$.

106. Kelo, 545 U.S. at 494.

107. Id. (O'Connor, J., dissenting).

108. Id. (O'Connor, J., dissenting). 
revitalization plan, as evidence of the satisfaction of the public use requirement. ${ }^{109}$ When the legislature's aim is to cure a pre-existing harm, such as in Midkiff and Berman, the public purpose was realized when the harmful use was eliminated. ${ }^{110}$ "Because each taking $d i$ rectly achieved a public benefit, it did not matter that the property was turned over to private use." 111 Here, Justice O'Connor argued, the result of the revitalization plan is a mere upgrade, adding only peripheral benefits to the public. ${ }^{112}$ These benefits are not meant to cure some pre-existing harm to the local landowners, such as the blight and unequal landownership dealt with in earlier eminent domain cases.

The dissenting Justices in the Kelo case laid the groundwork for a bevy of criticism aimed at the Supreme Court, with some states showing concern over the potential for abuse of eminent domain power by the government. ${ }^{113}$

In contrast, other scholars contend that the words "public use" as written in the Fifth Amendment are no more than a description of a type of taking that is compensable. ${ }^{114}$ Scholars argue that "the members of the founding generation generally understood that the power to take property for public use is reserved to the legislature alone and is a function of the principle of consent inherent in a representative government." 115 As a result, those who read the public use requirement as a limitation on the legislative power of eminent domain are misreading the intent of the drafters. ${ }^{116}$

However, as discussed below, characterizing the phrase "public use" as descriptive rather than limiting renders its inclusion a nullity. Further, if property rights are properly placed in the class of fundamental rights, then the infringement of that right for the purpose of a public use must be examined under heightened judicial scrutiny.

\section{A Proposal for the Future of the Public USE REQUIREMENT}

There are two changes the Court must make in order to protect the people's individual right to property. First, the Court must narrow the definition of public use to fit within the original intent of the founders. Second, the Court must recognize the right to property as a fundamental right, thereby making it subject to strict judicial scrutiny. Further, the Court must expand upon Justice Kennedy's concurrence in

109. Id. at 501.

110. Id. at 500 .

111. Kelo, 545 U.S. at 500 (O'Connor, J., dissenting).

112. Id. at 501 .

113. See, e.g., Justin B. Kamen, A Standardless Standard: How A Misapplication of Kelo Enabled Columbia University to Benefit from Eminent Domain Abuse, 77 Brook. L. Rev. 1217 (2012); Gold, supra note 46, at 1119.

114. See, e.g., Harrington, supra note 8, at 1248.

115. See, e.g., id. at 1247.

116. Id. at 1248 . 
the Kelo case, and find that eminent domain takings performed for the reason of economic revitalization must be viewed with a rebuttable presumption of invalidity.

\section{A. The Definition of Public Use Must Fall Within the Original Intent of the Founders}

As discussed above, lack of historical documentation as to the founders' intent in writing the Fifth Amendment has left a void when trying to determine the true meaning of public use. However, if we look at the language of the Fifth Amendment, the modern interpretation of what constitutes a public use is much broader than what the text intends. ${ }^{117}$ Indeed, if the founders intended a broad definition of public use, that is, "if the only requirement were that the federal government be acting pursuant to a legitimate purpose, then no phrase would be needed at all, since that requirement is implicit throughout the Constitution." 118 The modern interpretation of public use is so broad as to be "simply duplicative of the legitimate-state-interest test that every deprivation of property must satisfy under the Due Process and Equal Protection Clauses."119

In fact, if the phrase "for public use" is not a narrowing requirement for the taking of land under the Fifth Amendment, then the clause is essentially meaningless. ${ }^{120}$ Specifically, the Fifth Amendment contains two other prepositional phrases beginning with the word "for" in addition to the phrase "for public use":

No person shall be held to answer for a capital, or otherwise infamous crime, unless on a presentment or indictment of a Grand Jury ...; nor shall any person be subject for the same offence to be twice put in jeopardy of life or limb; . . . nor shall private property be taken for public use, without just compensation. ${ }^{121}$

In each case, "the prepositional phrase cannot be read as broadening rather than narrowing the clause's scope." 122

At this point, the Court has failed to address the argument that the phrase "for public use" must be a narrowing of the Amendment. Instead, the Court holds that the narrow view of public use as strictly "use by the public" has been eroded over time, and the expansive modern view of public use is a product of the State's police powers. ${ }^{123}$ The strict public use requirement is dismissed as a test too difficult to administer and supposedly proved to be "impractical given the diverse

117. Falls, supra note 2, at 369.

118. Roger Clegg, Reclaiming the Text of the Takings Clause, 46 S.C. L. REv. 531, 537 (1995).

119. Jed Rubenfeld, Usings, 102 Yale L.J. 1077, 1079 (1993).

120. Id. (citing Richard Epstein, TAKINGs 161 (1985)).

121. U.S. CONST. amend. V (emphasis added).

122. Clegg, supra note 118, at 537.

123. Kelo v. City of New London, 545 U.S. 469, 479 (2005). 
and always evolving needs of society." 124 This language is curious, however; a judicial determination over whether or not condemned property will be used by the public would seem necessary when the elimination of an individual's property rights are at stake.

Further, as discussed below, while it is true that legislatures often use their eminent domain powers for the economic benefit of their community, the increasingly expansive definition of public use fails to properly reflect the intent of the founders. ${ }^{125}$ The Supreme Court need not look any further than the text of the Fifth Amendment and eschew the expansive modern definition of public use in favor of the intended narrow definition.

\section{B. The Right to Property Is a Fundamental Right and Must Be Subject to Strict Judicial Scrutiny}

While the right to property is listed in the Fifth Amendment alongside the rights of life and liberty, which have long been held to be fundamental rights, it has not enjoyed the same judicial protection. If we follow the line of thinking that the framers viewed property rights as tantamount to liberty interests, then the public use requirement of the Fifth Amendment must be viewed as protecting a fundamental right. ${ }^{126}$ It is well established that when reviewing a violation of a fundamental right, the courts use a heightened form of judicial scrutiny. ${ }^{127}$ While the government's exercise of its eminent domain power emanates from its police power, this police power cannot burden an individual's fundamental right without first passing a heightened standard of judicial review. ${ }^{128}$

When examining a constitutional violation under strict scrutiny, the court looks to whether or not the legislative enactments are narrowly tailored to serve a compelling state interest. ${ }^{129}$ While legislative determinations subject to strict scrutiny are routinely held to be in violation of the Constitution, invocations of the public use requirement rarely meet the same fate. The Land Reform Act of 1967 as described in the Midkiff case is a good example. The legislation was written with the goal of equalizing the housing market in the State of Hawaii. ${ }^{130}$ The law itself is narrowly tailored to achieve this goal, as the Act would have little relevance once the housing market was adjusted. Further, a compelling state interest was delineated by the Hawaiian legislature. ${ }^{131}$ The inflated real estate prices resulting from the majority of

124. $I d$.

125. See, e.g., Tschetter, supra note 60 , at 226.

126. See Treanor, supra note 16 , at 709 .

127. See Washington v. Glucksberg, 521 U.S. 702, 721 (1997).

128. Id. at 722 .

129. Roe v. Wade, 410 U.S. 113, 155 (1973).

130. See Hawaii Hous. Auth. v. Midkiff, 467 U.S. at 241.

131. See $i d$. 
the state's land being concentrated within relatively few owners were a legitimate threat to the public welfare. ${ }^{132}$ Thus, Hawaii's Land Reform Act of 1967 would likely have survived a strict scrutiny review by the courts.

An example of a legislative determination that is less likely to survive strict scrutiny is one similar to the integrated development plan passed in the Kelo decision. In making its determination that its redevelopment plan was a valid public use, the City of New London cited Connecticut's legislative declaration of a policy recognizing that the state's "economic welfare" hinges upon the "growth of industry and business." 133 Therefore, "permitting and assisting municipalities to acquire and improve unified land ... for industrial and business purposes . . . are public uses."134 This broad declaration of what constitutes a public use is less likely to survive strict scrutiny. No explicit goal is mentioned, only a blanket statement that the state may procure lands for "industrial and business purposes."135 Therefore, legislative determinations such as that of New London's City Council are unlikely to be narrowly tailored enough to pass strict scrutiny.

Eminent domain is one of the most powerful tools wielded by the government. The power to deprive a person of property should not be subject to a lower standard of review such as rational basis that almost guarantees the government prevails. It is clear then, that the courts must act to provide more protection for individual property rights with the stricter form of scrutiny reserved for other fundamental rights such as life and liberty. The State should have the burden to show that the public's need for a particular piece of private property serves a compelling government interest, and the forced transfer of land should only occur in exigent socioeconomic circumstances. ${ }^{136}$

\section{In the Alternative, Takings Under the Pretense of Economic Development Must Overcome A Presumption of Invalidity}

When legislation "on its face ... [falls] within a specific prohibition of the Constitution," the Court is required to use a heightened form of scrutiny. ${ }^{137}$ While Justice Kennedy in his concurrence in the Kelo case states that a "presumption of invalidity is not warranted for economic development takings in general," he does agree that a more stringent standard of review than that announced in Berman and Midkiff might be appropriate for a more narrowly drawn category of takings. ${ }^{138}$

132. Id. at 242.

133. Conn. Gen. Stat. § 8-186 (2004).

134. Id.

135. Id.

136. See generally Jones, supra note 98 , at 312.

137. Falls, supra note 2, at 376 (citing United States v. Carolene Prods. Co., 304 U.S. 144, 153 (1938)).

138. Kelo v. City of New London, 545 U.S. at 493 (Kennedy, J., concurring). 
There is judicial precedent for a heightened standard of review when making a legislative determination that seems to violate a specific prohibition in the Constitution. ${ }^{139}$

Justice Kennedy's test would trigger a heightened form of review in a narrower category of cases, such as when a legislature decides to invoke its eminent domain powers for anything that, on its face, is not a public use. Justice Kennedy frets that a "broad per se rule or a strong presumption of invalidity ... would prohibit a large number of government takings that have the purpose and expected effect of conferring substantial benefits on the public at large and so do not offend the Public Use Clause." ${ }^{140}$ However, just as Justice Kennedy has acknowledged, "there may be categories of cases in which the transfers are so suspicious, or the procedures employed so prone to abuse, or the purported benefits are so trivial or implausible, that courts should presume an impermissible private purpose."141

In order to rebut the presumption of invalidity, all the State would have to show is the transfer of land is not aimed at conferring "benefits on particular, favored private entities, and with only incidental or pre-textual public benefits." 142 While this more moderate approach still fails to sufficiently protect property rights as fundamental or within the intent of the founders, it does provide more protection than what currently exists. Additionally, by delineating what triggers a review under heightened scrutiny, this framework may lead to less litigation and a more efficient land development process.

In summary, with such an expansive definition of public use, and the Court's unfettered deference to legislative determinations, the current judicial approach fails to protect the people from unjust takings. A heightened standard of review for takings outside the narrow view of a public use, while not ideal, would provide increased protection for individual property rights without being insurmountable for legislatures.

\section{Conclusion}

As America grows older, the need for urban revitalization has increased. The use of eminent domain by Congress and state legislatures as a means of effectuating change has grown in recent times. With this advent of a heavier reliance by the government on eminent domain comes the need for reform. While the government has an interest in using eminent domain to protect the public welfare, such protection should not come at the expense of the fundamental rights of the people. The power of eminent domain is unique in this respect;

139. United States v. Carolene Prods. Co., 304 U.S. 144, 153 (1938)

140. Kelo, 545 U.S. at 492 (Kennedy, J., concurring).

141. Id. at 493.

142. Id. at 490 . 
the sovereign's inherent power over the lands under its control must harmonize with the peoples' fundamental right to property. While a broad definition of public use is inherently a limitation in theory, courts rarely overturn a legislative determination of public use. ${ }^{143}$

Though the use of strict scrutiny for public use determinations would be consistent with the founders' intent, even a heightened form of review for a narrow category of cases would provide more protection for property rights. The current lack of a judicial check on the government's use of eminent domain tips the scales too far in favor of the government. The expansion of the public use requirement has made it virtually impossible for a landowner to successfully challenge a public use determination by a legislature, and the time has come for the Court to properly regulate the eminent domain power of the legislature.

143. The Public Use Limitation on Eminent Domain: An Advance Requiem, 58 YAle L.J. 599, 608 (1949) ("True, even a broad concept of "public use" implies a limitation, and many state courts still accord vocal acknowledgment to the concept. But they invariably find that the particular project under consideration is satisfactorily public in nature."). 